\title{
Geomorphological Traces of the Younger Pleistocene Glaciation in the Central Part of the Velebit Mt.
}

\author{
Bognar Andrija, Faivre Sanja
}

\begin{abstract}
On the central part of the Velebit Mountain the traces of the Pleistocene glaciation have been found. The domination of the dissected relief, characterized by numerous elevations and depressions, in the conditions of low temperatures and richess of snow precipitation during the Pleistocene were a very good predisposition for glaciation development on the central part of the Velebit Mt.
\end{abstract}

Key words: moraines, Pleistocene, glacial valleys, cirques, plateau glaciers, Velebit Mt. Croatia

\section{Geomorfološki tragovi glacijacije u mlađem pleistocenu na Srednjem Velebitu}

Na području Srednjeg Velebita utvrđeni su tragovi pleistocenske oledbe. Dominantna mrežasta struktura reljefa karakterizirana nizom uzvišenja i udubljenja u uvjetima niskih temperatura i bogatstva snježnih padalina tijekom pleistocena bili su iznimno povoljna predispozicja za razvoj oledbe na istraživanom području.

Ključne riječi: morene, pleistocen, dolinski ledenjaci, cirkovi, plato ledenjaci, Velebit, Hrvatska

\section{INTRODUCTION}

In the last 150 years there have been more and more researches of the past glacial periods, but total comprehension of the environments and related processes is still limited. As we learn more about glaciation, it seems that it was more complex than it had been thought at first. It is difficult to say where and when the first explanations have been mentioned, but by the middle of the $18^{\text {th }}$ century, some scientists in Scandinavia, Germany, Island and Switzerland suggested that in the past glaciers had covered a much more important area (Flint, 1947, 1957, 1971; Charlesworth, 1957, Embleton and King, 1968; Imbrie and Imbrie, 1979; Nilsson, 1983). In the $19^{\text {th }}$ century, Charpentier, Agassiz, Buckland and Esmark (only several authors singled out) realised that large European regions had been covered with ice. So a glacial period conception was created. However, at the beginning 
that conception was not accepted, although, till the late 1920s there were individuals in many parts of Europe and North America who doubted the idea of glacial period. Already in 1866, Archibald Geikie interpreted unlitificated sediments and relief forms in Scotland as proofs of glaciation. Then followed a period of geological and geomorphological mapping on the whole northern hemisphere. Till the mid-thirties, the knowledge about expansion of numerous glaciations which had swept over Europe and North America was well established (Flint, 1947, Charlesworth, 1957).

At the beginning of the $20^{\text {th }}$ century, the question of glacial period preoccupied numerous scientists in our country, as well. For the first time glaciation was mentioned by Hranilović (1901) in the Bulletin of the Croatian Naturalists' Society. Glaciation traces on Velebit were researched by Gavazzi in 1903, and by Schubert in 1910. A complete morphologic presentation of the Northern Velebit massif was made by Bauer in 1935, where he described many forms and sediments of glacial origin. A positive opinion of Velebit glaciation was also set out by a Hungarian biologist Degen (1936-1938). Only more recent researches of Nikler, (1973) and Belij, (1985) proved the existence of glaciation in Southern Velebit, while the researches of Bognar, et al. $(1991,1997)$ and Faivre $(2006)$ proved that in Northern and Central Velebit. Glacial sediments in the Dinarides were also recently studied by, Bognar et al. (1995), Bognar and Prugovečki (1997), Marjanac and Marjanac (2004), and Marjanac and Marjanac (2006).

\section{RELIEF PREDISPOSITIONS FOR DEVELOPMENT OF GLACIATION}

Although somewhat lower than Northern Velebit, owing to its relief dissection, Central Velebit had also predispositions for accumulation of big snow quantities and development of glaciers, but in somewhat lesser volume. Its dissected relief is marked by a series of summits - elevations and poljes, uvalas and dolines - depressions. Central Velebit is characterised by three parallel ridges stretching in the NW-SE direction. The middle one with the summits Zečjak (1,622 m), Šatorina (1,624 m), Lisac (1,449 m), Budakovo brdo $(1,317 \mathrm{~m})$ and Visibaba $(1,160 \mathrm{~m})$ is the highest; the eastern ridge with the summits Golić (1,552 m), Debeljak (1,500 m), Laktin vrh (1,504 m), Rusovo $(1,333 \mathrm{~m})$ and Metla $(1,288 \mathrm{~m})$ is a little lower, and the western one, where appear Visibaba $(1,448 \mathrm{~m})$, Kurozeb $(1,168 \mathrm{~m})$ and Velinac $(1,000 \mathrm{~m})$ is the lowest. Between the middle and eastern ridges there is karst polje basin of Štirovača, while between the central and eastern ones numerous uvalas appear, such as Mlinište, Radlovac, Vrbanska duliba and Duboka. Central Velebit is gradually sloping towards Southern Velebit, i. e. towards the saddle Baške Oštarije (924 m), and in the north towards the deep Bakovac valley which divides it from Northern Velebit.

\section{CIMATE PROPERTIES OF THE VELEBIT REGION IN QUATERNARY}

Together with numerous separated frozen surfaces in the mountains and on islands, 27 per cent of land was frozen in the Northern hemisphere. As the last glaciation finished recently, only 10,000 years ago, numerous traces of its existence are still preserved today. 
Bognar Andrija, Faivre Sanja - Geomorphological Traces of the Younger Pleistocene Glaciation in the Central Part of the Velebit Mt.

According to them the course of the climate changes in the last cold period of the Pleistocene glaciation can be reconstructed (Šegota, T. and Filipčić, A., 1996).

Analysis method of oxygen isotopes $\mathrm{O}^{18}$ and $\mathrm{O}^{16}$ in the shells of benthic foraminiferas from the deep-sea sediments is mostly used for determination of glacial periods (Shackleton and Opdyke, 1973). Although this method is not completely reliable, it has enabled a great progress and quickened numerous further researches.

The last glacial period in Europe (Würm) started 70,000 years ago, when optimal conditions developed. Expansion of ice cover depended on a very delicate balance between the influence of the summer month temperatures and precipitation quantity in winter. A too low temperature is a limiting factor of the ice cover development, because with a too low temperature another limiting factor comes, a too small quantity of snow. Therefore, ice cover stays where temperature is not under the optimum lower limit and there is enough precipitation, i.e. near a source of humidity (in this case, near Mediterranean).

Evolution of ice covers, i.e. their pulsating mechanism, is the consequence of functional relation between temperature and precipitation. The last glacial period started with a fresh and humid climate, and ended with a cold and dry one 10,000 years ago. When temperature dropped to the lowest level, ice covers started to withdraw. The temperature was too low for their further existence. Then precipitation quantity could have a crucial significance, but it was too small. Even the lowest temperatures by themselves cannot keep ice cover if there is not enough precipitation (Šegota and Filipčić 1996). So Klein (1953) calculated that in the maximum of the last glacial period in Europe there was 2080 per cent less precipitation than today. In our regions, too, in the maximum of the last glacial period, there was less precipitation than today, but relative decrease was greater inland (30-40\% than the present-day precipitation quantity) than in the mountain belt and on the coast (40-70\% of the present-day precipitation quantity). As to geomorphologic processes, it is essential to point out that a relative share of snow in total precipitation was much greater than today.

Traces of pre-glacial karst relief (formed in warmer periods - interglacials and interstadials) vary from completely destructed to those well preserved. But glacial periods are also marked by development of karst relief forms (Ford and Williams, 1994). On the basis of isotope analysis $\left(\mathrm{O}^{18}\right.$ and $\left.\mathrm{O}^{16}\right)$ (Shackleton and Opdyke, 1973) it has been stated that the interglacial climate was warmer or equal as today, and it was probably favourable to intensive development of karst relief forms. Warmer climate of the interglacial RissWürm, as well as that of the interstadial were surely favourable to that process. However, they were, in large measure, transformed by additional influence of ice (e.g. dolines and uvalas) or completely destructed e. g. karren and kamenitze (Perica, 1998).

More recent researches have shown that during the greatest drop in temperature, the annual temperature was 10-12 per cent lower than today. Studying periglacial processes and forms in Pannonia Poser (1947) calculated the average annual temperature of $-2{ }^{\circ} \mathrm{C}$ during the maximum Würm glaciation. On that basis Klein (1953) calculated mean monthly and mean annual temperature of air for Zagreb. Regarding the difference between the air temperature in Würm and today`s one in Zagreb, the air temperatures in Velebit region were 
calculated, Bognar et al. (1997). In that way the obtained July temperatures correspond to the isotherms on the Gates' map (Gates, 1976). The Adriatic Sea level of that period was -96 m lower (Šegota, 1982), and the coastal line that reached the outer edge of the Kornati islands (near the island of Mana) was $51 \mathrm{~km}$ away from the closest spot (near Jasenice). It was surely felt in weaker influence of the sea on climatic circumstances that is on more expressed continental influence on the SW slope of the Velebit Mt. Then the average air temperature in $129 \mathrm{~m}$ high "Karlobag" figured out at $2.2^{\circ} \mathrm{C}$, and in $115 \mathrm{~m}$ high "Senj" at $1.1^{\circ} \mathrm{C}$. Isotherm of $0^{\circ} \mathrm{C}$ was then at the height of approximately $400 \mathrm{~m}$ (consistent with the vertical gradient Senj - Baške Oštarije) (Perica, 1998). According to Messerli (1967) the mean monthly air temperature of the warmest month at the level of the snow-line is $4.5^{\circ} \mathrm{C}$, but because of specific local conditions for precipitation, evaporation and insolation it can be lower or higher for $1.3-1.4^{\circ} \mathrm{C}$.

According to Šegota (1963), intensified atmospheric circulation at the beginning of glaciation causes certain augmentation of precipitation, probably for 20 per cent at least, and solid precipitation prevails. The ice cover expansion after certain time (most probably around the middle of glaciation) starts to reflect itself negatively on precipitation. Because of exceptionally low temperatures the evaporation from the sea decreases, and the precipitation quantity starts to decrease gradually to reach the minimum in the period of the greatest drop in temperature. Precipitation is brought mainly by southern and western winds. Solid precipitation prevails more and more, and almost to the full during the maximum drop in temperature (Šegota, 1963, Šegota and Filipčić, 1996). Velebit receives a relatively large quantity of precipitation because of the sea closeness and favourable air circulations. According to the map of Europe by Klein (1953), during the Würm glaciation in the Velebit region that quantity of precipitation was averagely for 30 per cent smaller than today. Under such conditions the region of Southern Velebit over 1,600 m (or 1,500 m of the present-day height) received over $2,000 \mathrm{~mm}$ of precipitation (Visočica $1,716 \mathrm{~m}$ received 2,018 $\mathrm{mm}$, and uvala Bunjevac in the summit part approximately 2,393 $\mathrm{mm}$ ). The foothills of Velebit in the Zrmanja river valley of that time, which followed the southern edge of the present-day Velebit channel (Perica, 1998), received the smallest quantities of precipitation (Novigrad $740 \mathrm{~mm}$, Senj $858 \mathrm{~mm}$, Karlobag $902 \mathrm{~mm}$ ).

Relatively big quantity of precipitation during the maximum drop in temperature in the Würm glacial period, a significantly lower air temperature and smaller evaporation were favourable to the existence of glaciers in higher, and snow cover in central and lower parts of Velebit. However, we should also mention "additional precipitation" coming from mist and clouds (hoar prevailed), which was surely of great importance (although its contribution was significantly smaller than the present-day relative values), in feeding glaciers and snow cover.

According to Höfer's method of snow-line determination as the arithmetic mean between the medium ridges height, which limits the glacier feeding territory, and the height of the glacier lower limit, the snow-line in Northern and Central Velebit could be established on the height of around 1,300 m. 
Bognar Andrija, Faivre Sanja - Geomorphological Traces of the Younger Pleistocene Glaciation in the Central Part of the Velebit Mt.

\section{MORPHOLOGIC TRACES OF GLACIATION}

Geomorphologic and geologic traces of the Pleistocene glaciation in the Central Velebit region have been discovered by mapping of that area for the needs of the project "Geomorphological mapping of the Republic of Croatia". This relates to exaration and accumulation morphologic elements, as well as to correlative sediments (Fig.1.). According to the data obtained by morphometric parameters analysis, to the reconstruction of the climate during the last glacial period, and to the expansion and spatial distribution of glacier morphologic forms, we can calculate that the glaciation affected the summit part of Central Velebit up to $1,300 \mathrm{~m}$ above sea level. In that part of Velebit glaciation had regional characteristics, it affected the area of $30.5 \mathrm{~km}^{2}$.

There were developed, similar to Northern Velebit, three glaciation types: valley, cirque and plateau. Plateau glaciers were formed in the area of the elevations Debeljak, Pjeskoviti bregovi and Javornik. Summit parts of those elevations have characteristics of dissected plateaus with numerous deep dolines (to $100 \mathrm{~m}$ of depth). All quoted dolines and the uvala Sunđerac in the interspace between Javornik and Pjeskoviti bregovi were filled up with ice. Consequently, just dolines had given frame to the accumulation of big quantities of snow (Fig.1.), from which then developed glacier's ice. It is evident that at the first stage of glaciation there were smaller cirque sources of ice mutually independent, and during the maximum glaciation those cirque glaciers joined into a plateau type. Apart from the case of the uvala Sunđer and tectonically predisposed dry valley leading towards Klepina duliba, it is not possible to determine any more the movement direction of the glaciers of Javornik, Debeljak and Pjeskoviti bregovi, which had a plateau character. They were probably melting by the escarpments towards the large uvala Klementa in the north and towards the Palež and Japage area in the east. This is supported by the development of a relatively large glacio-fluvial fan on the slope of Debeljak (towards the uvala Klementa), as well as by the fact that the moraine material determined on the eastern slope of Debeljak and Pjeskoviti bregovi (towards Palež and Japage) does not form typical moraines but covers the slope completely (Fig.2., Fig.3.).

Plateau glacier was also nicely developed in the wider region of Šatorina, where, besides, a whole series of glacial troughs was formed. The trough system northwards from Šatorina is together with its source tied to the system of deep dolines in the region of Borovačko brdo, Paleški golić, Pištolin golić, Medin golić, Medveđak and Crni Vrh formed on a relatively planated block westwards of Štirovača. We can presume that it was a case of one plateau glacier whose tongues were oriented in the SE direction towards Dokozina plan. Namely, going from Dokozina plan towards the NW, there is a system of tectonically conditioned karst depresions, probably along the faults stretching NW-SE. This caused three valley glaciers formation. The first one is tied to the system of dolines and dry valleys Klade-Ljuljevac. The second, the largest one, system of mutually linked dolines which was filled up with ice, expands from Osočki dolac across the uvalas Veliki and Mali Ileksinovac and further from Vodeni dolac to Dokozina plan. The third glacier, stretched along the dry valley starting from the toponym Dulibice under the elevations Lukšanovac and Ograđenik. Going towards the east, that glacier was probably linked with the glacier of Dokozina plan. The length of the discovered end moraine in the area of Dokozina plan, 


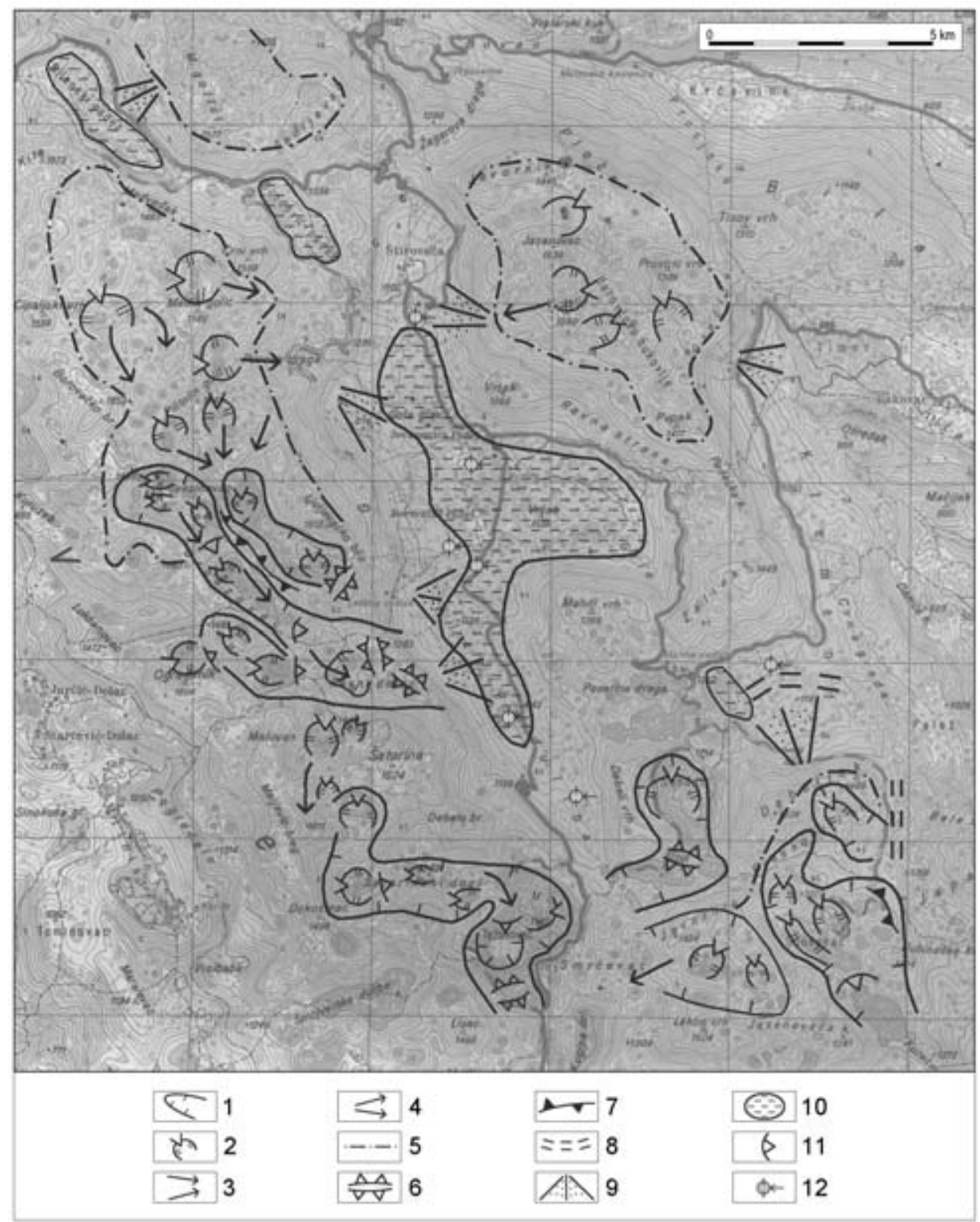

Fig. 1 Geomorphological traces of the younger Pleistocene glaciation in the central part of the Velebit Mt Sl. 1. Geomorfološki tragovi glacijacije u mlađem pleistocenu na Srednjem Velebitu

Legend: 1. glacial valley; 2. glacially reshaped fossil doline; 3 . direction of ice convergence; 4 . direction of ice divergence; 5. supposed maximum spreading of glaciation; 6. end moraine; 7. lateral moraine; 8. moraine in general; 9. glacio-fluvial fan; 10. lacustrine basin; 11. sub-glacially eroded steps; 12. ponor

Legenda: 1. ledenjačka dolina; 2. fosilna ledenjačka ponikva; 3. pravac ledenjačke konvergencije; 4. pravac ledenjačke divergencije; 5. pretpostavljena makimalna rasprostranjenost oledbe; 6. čeona morena; 7. rubna morena; 8. morena uopće; 9; glaciofluvijalna plavina; 10. jezerski bazen; 11. ledenjački pregib; 12. ponor 
above the escarpment towards Klepina duliba, figures out at about $500 \mathrm{~m}$, and is elongated in the direction NW-SE. This moraine is composed of very heterogeneous material, blocks, rock debris, and silt (Fig. 4.). The glacier of Dokozina plan was about $4 \mathrm{~km}$ long, that of Ljuljevac about $1.5 \mathrm{~m}$, and the glacier Dulibice somewhat more than one kilometre (Fig.1.). In the case of the glaciers Dokozina plan and Dulibice sub-glacially eroded steps have been clearly noted. All parts of the karst depression bottoms have not been researched so far because of a very hard terrain, so we can only presume the existence of a ground moraine and a sequence of smaller recessional or stadial moraines. Their discovery and mapping are the tasks of further research. Gullies that conducted glacier meltwater towards Klepina duliba, which apparently represented a lake at that time, are nicely observable. The biggest quantities of water were probably the result of the Ljuljevac glacier`s melting. Three large gullies emerged on the tectonically predisposed escarpment towards Klepina duliba. A fluvio-glacial fan was formed in its bottom near the source Ledena vodica.

The other large glacier source was located in the area of Šatorinski doci, that is southwards from the summit Šatorina. There is also a whole series of deep dolines, which played the role of cirques during the Pleistocene. Dry valley that connects them has a " Z" shape of longitudinal profile, which points to tectonic predisposition of its formation. Characteristic " $U$ " transversal profile of the Šatorinski doci dry valley and sub-glacially eroded steps are indisputable proofs of exaration formation of the limestone basis. Only one moraine has been discovered, and it is located on the southern edge of the uvala Težakovac, near Kugina kuća (Fig.1.). The moraine, $300 \mathrm{~m}$ long, was primarily characterised by blocks of accumulated glacial material. The length of the glacier Šatorinski doci was about $4.5 \mathrm{~km}$.

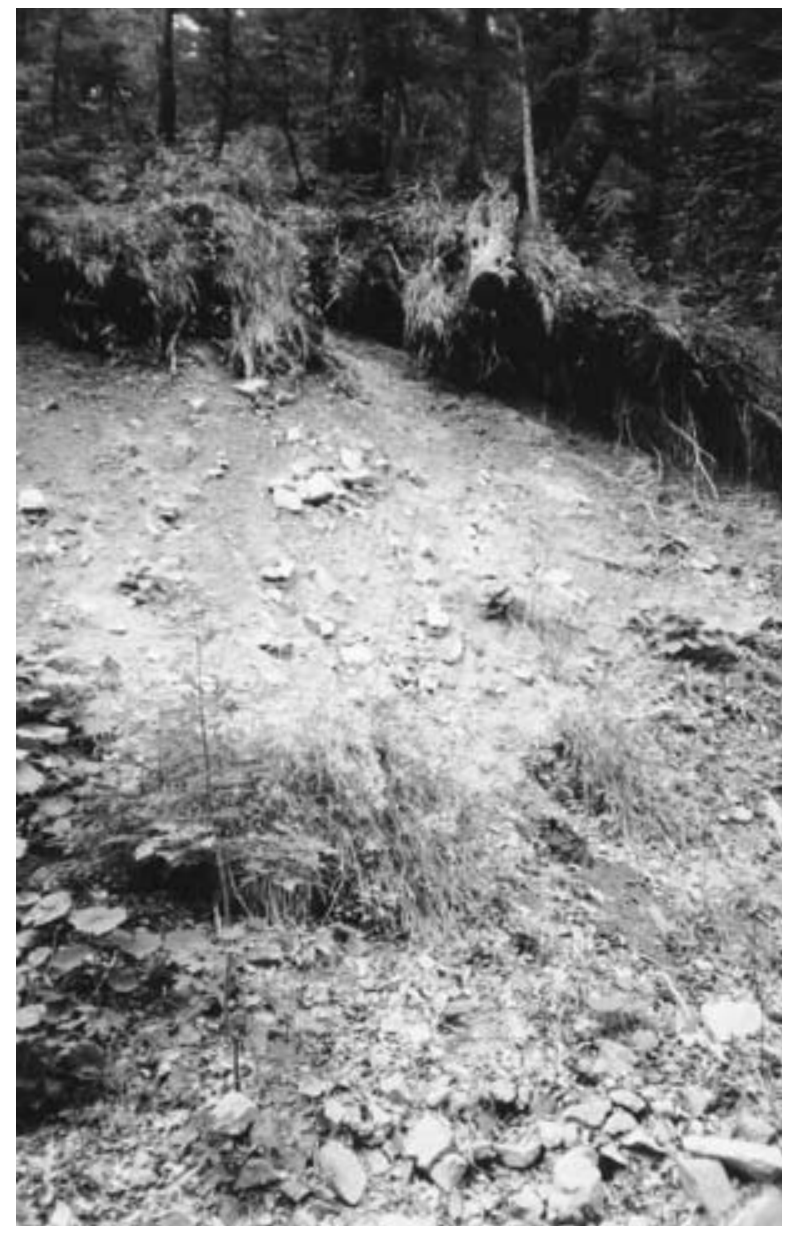

Fig. 2 Lateral moraine of the plateau glacier on the mountain block of Debeljak-Pjeskoviti bregovi

Sl. 2. Rubna morena platoastog ledenjaka na gorskom bloku Debeljak-Pjeskoviti bregovi 


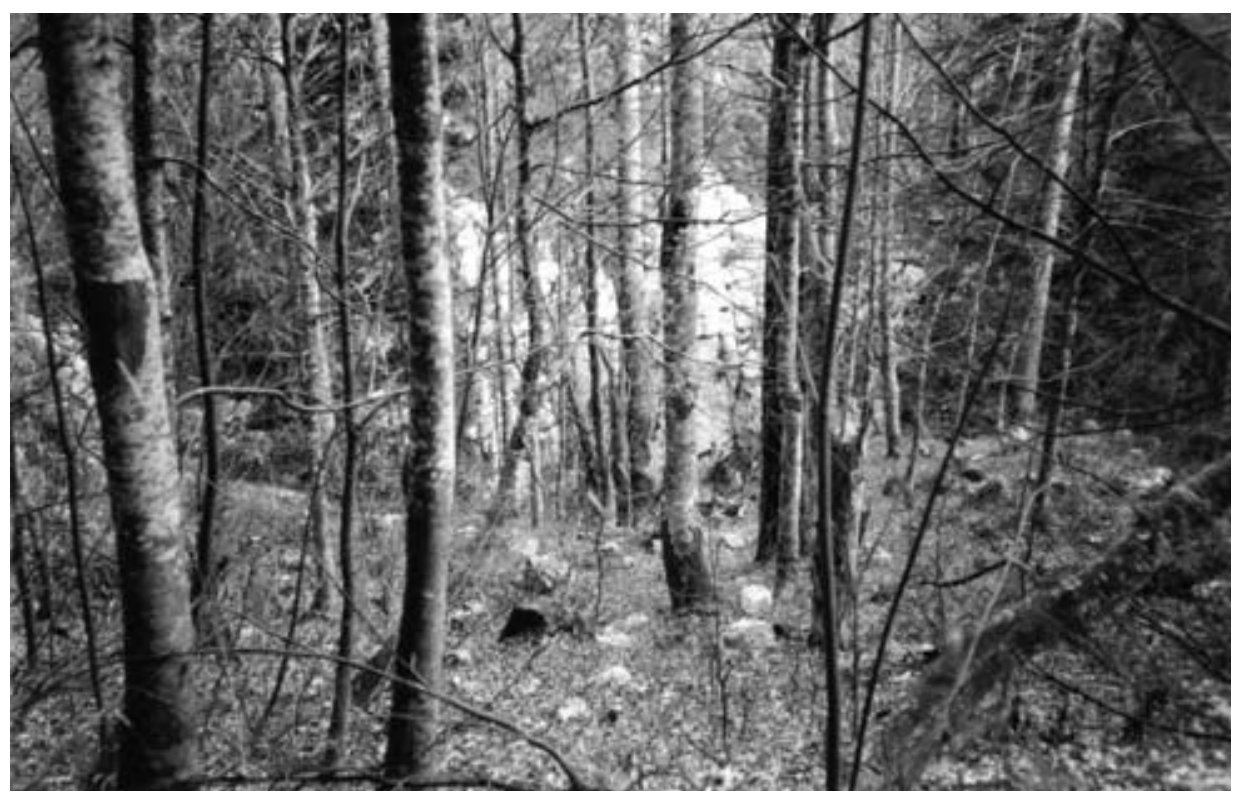

Fig. 3 Moraines beneath Debeli vrh redeposited by outwash

Sl. 3. Podledenjačkim potokom pretaložene morene ispod Debelog vrha

Although the traces of lacustrine sedimentation have not been found yet, we presume that during the Pleistocene, the meltwater made lakes in the depressions of today`s uvalas of Padež, Štirovača karst polje-basin and today's dry valley of Klepina duliba. As most of the drift accumulated by the meltwater was of carbonate structure, it is very probable that a larger part of that drift was dissolved at warmer stages of glaciation and older Holocene, then by the underground drainage system (Kuhta, 1990) transported and deposited in the area of the river Otešica, in the polje of Lika and in the area of the present-day Velebit channel. This is supported by a whole series (several dozen) of ponors (Fig.1.) under the scope of the Štirovača karst polje-basin and Klepina duliba dry valley, as well as by the structure of so called "proluvial sediments" of the Pleistocene age in the region of the polje of Lika and Otešica river valley: loams, clays, sand-clays, sands and gravels, the thickness of which in places surpasses $15 \mathrm{~m}$ (Explanatory notice of the Main geological map 1:100 000, sheet Gospić, 1976). These sediments lie on a karstified carbonate basis and, in relatively large areas, form a typical landscape covered with heaths and birch woods. More delicate deposit fractions represented, in petrographic sense, by loams, clays and sand-clays, dominate in these "proluvial sediments" (according to the Main geological map, sheet Gospić), while gravels and sharper sands appear in subordinate quantities. It would be logical to presume that during the Pleistocene, because of marked cryofraction and glaciation in the Velebit region, prevailingly sharper material accumulated, and was then transported by torrent meltwater and settled in the area of local erosion bases such as the Otešica river valley, the bottom of the polje of Lika and the bottom of the present-day Velebit channel, which was then a land surface. On the contrary, as mentioned before, "proluvial" sediments are represented by prevailingly more delicate fractions in the mineralogical structure 
Bognar Andrija, Faivre Sanja - Geomorphological Traces of the Younger Pleistocene Glaciation in the Central Part of the Velebit Mt.

of which, especially in lower parts of the layers, a group of resistant minerals prevails: tourmaline - zircon - rutile. Such mineralogical structure points to the Velebit origin of the layers prevailingly form the area where limestones and dolomites prevail in structure. Predominance of heavy minerals such as epidote - coisit - amphibol, in the upper parts of "proluvial sediments" indicates that towards the end of the Pleistocene, and, maybe, in older Holocene as well, bringing material from the regions where clastic layers prevailed was predominant. It is evident that we must think about a series of clastic sediments of the Palaeozoic age in the area of Počitelj, Divosel, Rizvanuša, Brušane and Trnovac. Such differences in mineralogical structure of those "proluvial sediments" make us assume that the surface system of "proluvial sediments" is not of the Pleistocene age, but of the earlier one - Holocene. Namely, by melting of glaciers and disappearance of lacustrine surfaces in the mountain region, the influx of drift characterised by more delicate fractions possibly ceased. The other possibility is that their quantity decreased with increasing melting of carbonates, so the arrival of drift from the lower parts of the Štirovača and Klepina duliba prevailed. In the structure of the extreme western edge of Štirovača and Klepina duliba clastic sediments of the Triassic age prevail: shale, sands, conglomerates, piroclastites, and clayed dolomites. Those impermeable layers with characteristic mineralogical structure where amphibol, epidote and coisite prevail have emerged on the surface by evacuation of the carbonate structure sediments. Just those sediments produced a larger part of the drift that was transported towards the polje of Lika, which explains the changes in minerological structure of the surface part of "proluvial sediments" of the Otešica river valley and those of the polje of Lika. Of course, we must add that this was contributed by destruction of clastic deposits (sands and shales), tuffs, tuffites and hornstone of the Triassic age from the neighbourhood of Donje Pazarište.

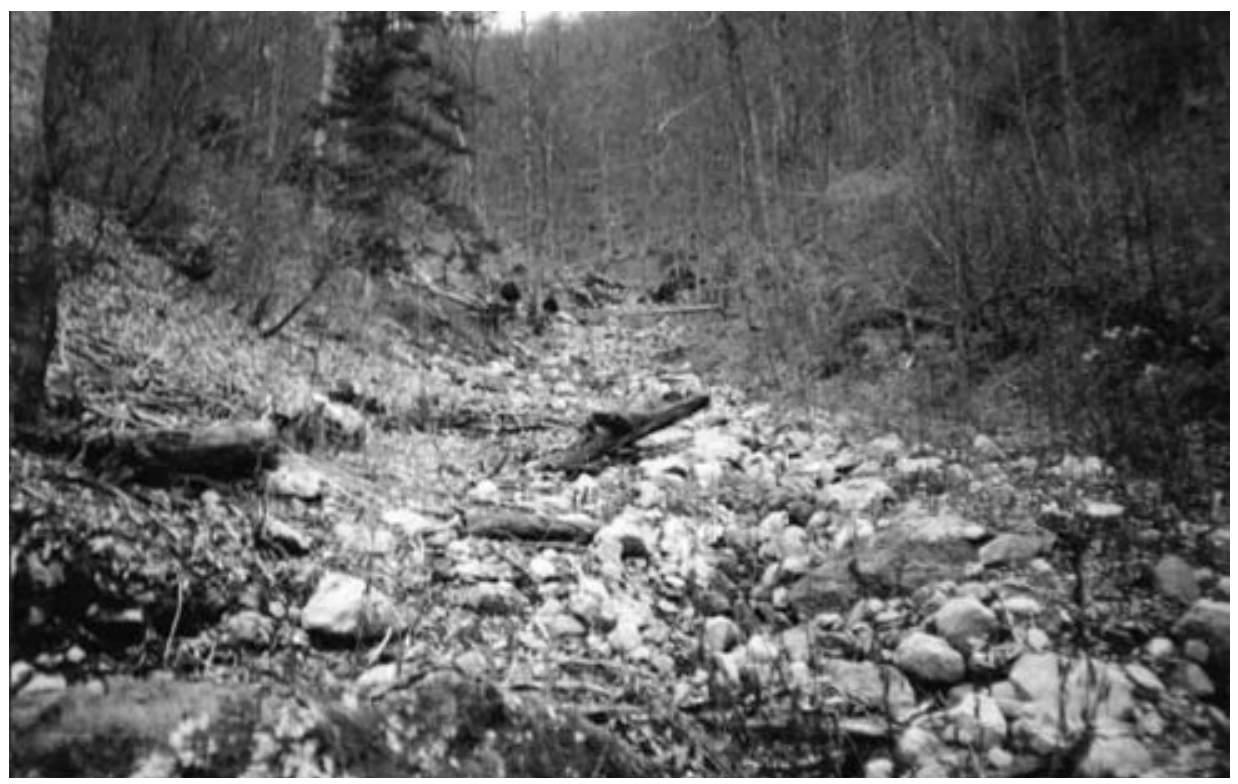

Fig.4 Profile of recessional or stadial moraine on the western slope of Klepina duliba

Sl. 4. Profil stadijalne morene na zapadnoj padini Klepine dulibe 


\section{CONCLUSION}

By its larger part Central Velebit is a high mountain region. There dominates a net-like relief structure characterised by a series of summits-elevations and depressions - poljes, uvalas and dolines. Such relief relations in the conditions of low temperatures and richness of snow during the Pleistocene were an exceptionally favourable predisposition for glaciation development in Central Velebit. It was characterised by formation of cirque, valley and plateau glaciers, which is supported by a sequence of discovered exaration and accumulation glacial morphologic forms and correlative sediments.

\section{REFERENCES}

Bauer, B., 1935: Über des Nordlichen Velebit, Jahresberichte des Bundes-Real-gymnsium Knittenfeld, p 49

Belij, S., 1985: Glacijalni i periglacijalni reljef Južnog Velebita, Posebno izdanje Srpskog geografskog društva 61, 5-68, Beograd

Bognar, A., Faivre, S., Pavelić, J., 1991: Tragovi oledbe na Sjevernom Velebitu, Geografski glasnik, 53, 27-39, Zagreb

Bognar, A., Pavličević, D., Pavelić, J. (1995) : Glaciofluvijalne plavine u izvorišnom dijelu bazena porječja vodotoka Velike Paklenice, Paklenički zbornik 1, 43-47, Starigrad-Paklenica.

Bognar, A., Faivre, S., Pavelić, J., 1997: Tragovi oledbe na Srednjem Velebitu , Senjski zbornik, 24, 1-16

Bognar, A., Prugovečki, I. (1997): Glaciation traces in the Area of the Risnjak Mountain Massif. Geologia Croatica, 50/2, 269-278, Zagreb

Charlesworth, J. K., 1957: The Quaternary Era, with Special References to its Glaciation, Edward Arnold, 1 700 p., London

Degen, A., 1936-38: Flora Velebitica, Sv. I-IV, Akademie der Wissenschaften, Budapest

Embleton, C. and King, C. A. M., 1968: Glacial and Periglacial Geomorphology, Edward Arnold, 608 p. London

Faivre, S., 2006: Some geomorphological aspects of the Velebit mountain range, Adria 2006 International Geological Congress on the Adriatic area, Field trip Guide, Ur. Menichetti, M. and Mencucci, D., Instituito di Science della Terra, Universita di Urbino, Urbino, Italija, 48-50

Flint R. F., 1947: Glacial Geology and the Pleistocene Epoch, John Wiley \& Sons, 589 p. New York

Flint R. F., 1957: Glacial Geology and the Pleistocene Epoch, John Wiley \& Sons, 553 p. New York

Flint R. F., 1971: Glacial and Quaternary, John Wiley \& Sons, 892 p. New York and London

Ford, D., Williams, P., 1994: Karst Geomorphology and Hydrology, Chapman and Hall, p. 1-601, London

Gates, W. L., 1986: Modeling the Ice-age, Climate science, Vol. 191

Gavazzi, A., 1903: Trag oledbe na Velebitu, Glasnik hrvatskog naravoslovnog društva 14, Zagreb

Geikie, J., 1863: On the phenomena of the glacial drift of the Scotland.Transactions of the Geological Society of Glesgow, 1, 1-190

Imbrie, J., and Imbrie, K., P., 1979: Ice Ages: Solving the Mystery, Enslow, 224 p. Hillside, NJ

Höfer, R., 1879: Gletscher und Eiszeitstudien, Sitz. Ber. d. Ak. d.,Wiss., Win

Hranilović, H., 1901: Geomorfološki problemi iz hrvatskog krasa, Glasnik hrvatskog naravoslovnog društva 19 , Zagreb 
Bognar Andrija, Faivre Sanja - Geomorphological Traces of the Younger Pleistocene Glaciation in the Central Part of the Velebit Mt.

Klein, A. M., 1953: Die Niederschläge in Europa im Maximum der letzten Eiszeit, Versuch einer Rekonstruktion aus dem Höhenunterschid zwichen damaliger und heutiger Schneegrenzlage, Petermans Geogra. Mittelungen., 97, 98, Gotha

Kuhta, M., 1990: Speleološka istraživanja na prostoru kompleksne hidrogeološke barijere Velebita lokaliteti Štirovača i Klementa, Speleologica croatica 1, 21-29, Zagreb

Messerly, B., 1967: Die eiszeitliche und die gegenwärtige Verletscherung im Mittelmeerraum, Geographia Helvetica 22, 105-228

Marjanac Lj.. Marjanac T., 2004: Glacial history of Croatian Adraitic and Coastal Dinarides. Quaternary Glaciations.

Marjanac T., Marjanac Lj., 2006: The glacial and proglacial deposits of south Velebit mt. (Velika Paklenica), Adria 2006, International Gelogical Congress on the Adriatic area, Field trip Guide, Ur. Menichetti, M. and Menucci, D., Istituito di Scienze della Terra, Univ. di Urbino, Urbino, 44-46

Nikler, L. 1973: Nov prilog poznavanju oledbe Velebita, Geološki vjesnik, Svezak 25, Institut za geološka isreaživanja u Zagrebu, Zagreb

Nilsson, T., 1983: The Pleistocene; Geology and Life in the Quaternary Ice Age, Dordrecht: D. Reidel, p. 651

Perica, D., 1998: Geomorfološke osobine krša Velebita, Doktorska disertacija, Geografski odsjek PMF-a, Sveučilište u Zagrebu, p. 258, Zagreb

Poser, H., 1947: Auftauftiefe und Frostzerrung im Boden Mitteleuropas Während der Würm-Eiszeit, Naturwisseschaften 34,232 und 262

Schubert, R., 1908: Zur Geologie des Osterreichischen Velebit Jahr, k. k. geol. R. A. 58, Wien

Shackleton, N.J., Opdyke, N.D. 1973: Oxigen Isotope and Paleomagnetic Stratigraphy of Equatorial Pacific Core V28-238. Oxigen Isotope Temperature and Ice Volumes on a 105 Year and 106 Year Scale, J. Quaternary Research, 3 (1) 39-55.

Sokač, B., Ščavničar, B., Velić, I., 1976: Tumač za list Gospić OGK

Šegota, T., Filipčić, A., 1996: Klimatologija za geografe, III izdanje, Školska knjiga, p. 1-472, Zagreb

Šegota, T., 1963: Geografske osnove glacijacija, Radovi Geografskog instituta, Sv. 4., 1-119, Zagreb

Šegota, T., 1982: Razina mora i vertikalno gibanje dna Jadranskog mora od riss-würmskog interglacijala do danas, Geološki vjesnik, 35, Zagreb

\title{
SAŽETAK
}

\section{Geomorfološki tragovi glacijacije u mlađem pleistocenu na Srednjem Velebitu}

\author{
Bognar Andrija i Faivre Sanja
}

Na području Srednjeg Velebita utvrđeni su tragovi pleistocenske oledbe. Dominantna mrežasta struktura reljefa karakterizirana nizom uzvišenja i udubljenja u uvjetima niskih temperatura i bogatstva snježnih padalina tijekom pleistocena bili su iznimno povoljna predispozicja za razvoj oledbe na istraživanom području.

Kartiranjem područja Srednjeg Velebita pouzdano su utvrđeni geomorfološki i geološki tragovi pleistocenske oledbe tog područja. To se odnosi na egzaracijske i akumulacijske morfološke elemente te na korelativne sedimente. Prema podacima dobivenim analizom morfometrijskih parametara, 
rekonstrukciji klime tijekom posljednjeg glacijala te raširenja i prostornog rasporeda ledenjačkih morfoloških oblika, može se računati da je oledba zahvatila vršni dio Srednjeg Velebita iznad 1 $300 \mathrm{~m}$ nadmorske visine. U tom je dijelu Velebita glacijacija imala regionalna obilježja, zahvatila je površinu od $30,5 \mathrm{~km}^{2}$.

Razvijena su bila, slično Sjevernom Velebitu, tri tipa oledbe i to: dolinski, cirkni i platoasti tip. Platoasti ledenjaci oblikovali su se na području uzvišenja Debeljak, Pjeskoviti bregovi i Javornika. Vršni dijelovi tih uzvišenja imaju obilježja diseciranih zaravni s brojnim dubokim ponikvama. Sve navedene ponikve pa i uvala Sunđerac u međuprostoru između Javornika i Pjeskovitih bregova bile su ispunjene ledom. Dakle, upravo su ponikve dale okvir akumulaciji velikih količina snijega iz kojeg se onda razvio ledenjački led. Očito da su u početnoj fazi oledbe tu postojala manja cirkna izvorišta leda međusobno neovisna, da bi u maksimumu oledbe došlo do spajanja tih cirknih ledenjaka i formiranja onog platoastog tipa.

Sustav trogova sjeverno od Šatorine svojim izvorištem također je vezan za sustav dubokih ponikava na području Borovačkog brda, Paleškog golića, Pištolinog golića, Medinog golića, Medveđka i Crnog Vrha oblikovanih na relativno zaravnjenom bloku zapadno od Štirovače. Može se predpostaviti da se i tu radilo o jednom platoastom ledenjaku čiji su jezici bili usmjereni u pravcu JI prema Dokozinoj plani. Tu su formirana tri dolinska ledenjaka. Prvi je vezan za sustav ponikava tj. udolinu Klade-Ljuljevac, drugi, za sustav međusobno spojenih duliba-ponikava Osočki dolac, uvalu Veliki i Mali Ileksinovac te Vodeni dolac prema Dokozina plani. Treći, dolinski ledenjak kretao se udolinom od toponima Dulibice ispod uzvišenja Lukšanovac i Ograđenik. Idući prema istoku taj se ledenjak vjerojatno spajao s ledenjakom Dokozina plane. Dužina otkrivene čeone morene u području Dokozine plane iznad strmca prema Klepinoj dulibi iznosi oko 500 m, a izdužena je pravcem SZ-JI. Ta je morena sastavljena od vrlo heterogenog materijala, blokova, kršja i silta. Ledenjak Dokozina plane bio je dug oko $4 \mathrm{~km}$, Ljuljevački oko 1,5 km a ledenjak Dulibice nešto više od jednog kilometra.

Drugo veće izvorište ledenjaka nalazilo se na području Šatorinskih dolaca dakle južno od vrha Šatorina. I tu je razvijen čitav sustav dubokih ponikava koje su imale funkciju cirkova tijekom pleistocena. Karakterističan „U” poprečni profil udoline Šatorinski doci i podledenjačke prečage nepobitni su dokazi egzaracijakog oblikovanja vapnenačke podloge. Otkrivena je samo jedna morena i to na južnom obodu uvale Težakovac, blizu Kugine kuće. Morena, dužine 300 m, prvenstveno je karakterizirana blokovima akumuliranog glacijalnog materijala. Dužina ledenjaka Šatorinski doci iznosila je oko $4.5 \mathrm{~km}$.

Predpostavljamo da je otopljena voda sočnica tijekom Pleistocena ujezerila udubljenja današnjih uvala Padeža, i zavale polja u kršu Štirovače i Klepine dulibe.

Received (Primljeno): 2006 - 09 - 30

Accepted (Prihvaćeno): 2006 - 10 - 27

Dr. sc. Andrija Bognar, full professor, Department of Geography, Faculty of Science, Marulićev trg 19, 10000 Zagreb, Croatia

e-mail: abognar@geog.pmf.hr

Dr.sc. Sanja Faivre, assistant professor, Department of Geography, Faculty of Science, Marulićev trg 19, 10000 Zagreb, Croatia

e-mail: sfaivre@geog.pmf.hr 